\title{
Detection of Somaclonal Variation in Micropropagated Plants of Sugarcane and SCMV Screening through ELISA
}

\author{
Abdullah $^{1}$, Smiullah ${ }^{1}$, Farooq Ahmad Khan ${ }^{1}$, Rameez Iftikhar ${ }^{2}$, M. Muzaffar Raza ${ }^{1}$, Rasheda Aslam ${ }^{1}$, \\ Ghazanfar Hammad ${ }^{1}$, Ambreen Ijaz ${ }^{3}$, M. Wasif Zafar ${ }^{1} \&$ Usman Ijaz $^{1}$ \\ ${ }^{1}$ Department of Plant Breeding and Genetics, University of Agriculture, Faisalabad, Pakistan \\ ${ }^{2}$ Agricultural, Food and Nutritional Science Department, University of Alberta, Edmonton, Canada \\ ${ }^{3}$ Department of Bioinformatics and Biotechnology, GC University, Faisalabad \\ Correspondence: Smiullah, Department of Plant Breeding and Genetics, University of Agriculture, Faisalabad, \\ Pakistan. E-mail: sami_1167pbg@yahoo.com
}

Received: December 27, 2012 Accepted: January 31, 2013 Online Published: March 15, 2013

doi:10.5539/jas.v5n4p199 URL: http://dx.doi.org/10.5539/jas.v5n4p199

\begin{abstract}
Callogenesis is a helping tool in tissue culture for creating variation. The study was carried out to investigate the response of different sugarcane varieties to callogenesis in order to analyze variation for sugarcane mosaic virus resistance. Three sugarcane accessions viz HSF-242, S2003-US-623, and S2003-US-633 were used in this study. The genotypes showed high value of callus score ranging from 2.59 to 3.25. Genotype HSF-242 was highest callus producer with an average score of 3.25. Three different media were used for organogenesis. S2003-US-633 proved to be the most responsive to organogenesis with an average of $43.33 \%$. Material was exposed to shooting and rooting media and somaclones were shifted to green house. The somaclones produced were screened for sugarcane mosaic virus by ELISA (enzyme linked immunosorbent assay). Among 10 parent plants and 32 somaclones of HSF-242, only four somaclones showed susceptibility to SCMV disease while seven (7) parents showed positive reaction to the disease. Somaclones produced were also analyzed by microsattelite molecular markers to check the variation between parents and somaclones produced at molecular level. Molecular markers are useful for assessment of variation and phylogenetic relationships. Out of thirty (30) fragments amplified with fifteen (15) primers used among the sugarcane somaclones and parents, eleven (11) bands were polymorphic while rest of the nineteen (19) bands were monomorphic. Therefore, it may be concluded from the present results that SSRs can be used for identification of somaclonal variation and the relationship between parents and Somaclones.
\end{abstract}

Keywords: callogenesis, somaclones, simple sequence repeats (SSR), genetic markers

\section{Introduction}

Sugarcane is an important food and cash crop in tropical and subtropical regions of the world especially in Pakistan. It is grown in a range of environments from hot humid near sea level to cool and moist environment at higher elevations. Pakistan ranks at the fifth position in cane acreage and production and almost 15 th position in sugar production in the world. In Pakistan, area under sugarcane production was 1241 thousand hectares and total sugarcane production for the year 2011-2012 was 63.9 million tons. Sugarcane shares in value added of Agriculture and GDP are $3.6 \%$ and $0.8 \%$, respectively (Anonymous, 2011-2012). The recovery of sugar can be increased from the current average of $8.32 \%$ to $10 / 11 \%$ by better cane varieties.

It is a photo-thermal sensitive crop and flowering takes place at $5-23^{\circ}$ latitude whereas Pakistan is situated at $24-37^{\circ}$ latitude. Other conditions required for changing the vegetative to reproductive phase are Temperature range of $25-33^{\circ} \mathrm{C}$ for 70 days, Humidity $70-80 \%$ for 70 days, Day Length $11.5-12.5$ hrs for 70 days. The low cane and sugar yields are attributed to many factors in which drought; salinity, insect pests, and diseases are major constraints (Nasir et al., 2000; Khaliq et al., 2005). High ploidy, low fertility, a large genome, complex environmental interactions, slow breeding advances, and backcrossing for the introduction of specific genes make conventional breeding difficult for this crop. In Pakistan, sugarcane flowers only in lower Sindh coastal areas, JabbanvalleyinMalakand agency, Khyber PakhtoonKhawa and at Murrree hills, but viability is still a problem due to unfavorable climatic conditions. Thus, lack of viable fuzz production makes it difficult to improve sugarcane through conventional breeding in Pakistan. 
By conventional methods usually $8-10$ years of work is needed to complete a selection cycle for an improved variety. Vegetatively propagated crops like sugarcane have also been genetically improved by issue culture techniques in relatively shorter time as compared to other conventional methods. During the last two decades, the techniques of plant tissue culture have been developed as new and power tool for crop Improvement. Callus culture of sugarcane have been successfully established using shoot apices, young leaves and young inflorescences as explant on MS medium containing 2, 4- D and coconut milk. These clones show variation for different traits like high yield, more sugar recovery, disease resistance, drought tolerance and early maturity etc (Niaz \& Quraishi, 2002a).

This technique is also used to make disease free plants in sugarcane by somaclonal variation. Technological advances in molecular biology have contributed substantially in understanding plant genetic diversity. Large numbers of DNA marker systems have been developed for the identification of genetic polymorphism.Among these microsatellite analysis or SSR marker has been one of the most important techniques. In addition, the existence of diseases in micropropagated plants of sugarcane can be checked by ELISA technique of virus detection, so it is very important to make disease free plants.

\section{Materials and Methods}

In this study two elite sugarcane accessions viz S-2003-us-623, S-2003-us-633 and one sugarcane mosaic disease susceptible variety HSF-242 were used and research work was performed at the Agricultural Biotechnology Research Institute AARI, Faisalabad. Young leaves and pith were used as explant sources and 2-3 mm pieces of leaf and pith explant sources after surface sterilization were aseptically cultured on solidified MS medium (Murashige \& Skoog, 1962) supplemented with 5 different doses $(1,2,3,4,5 \mathrm{mg} / \mathrm{l})$ of 2,4-D levels in test tubes. Each test tube was filled with $10 \mathrm{ml}$ medium and after incubating in dark at $28^{\circ} \mathrm{C}$ for first two weeks tubes were shifted under continuous florescent light of 2000 to 2500 lux intensity at the same temperature. The data were analyzed statistically using completely randomized design.

The resulting calli were subjected to regeneration@1-2 g of callus per test tube in three different types of regeneration media; RM1 $=$ MS basal media $+1 \mathrm{mg} / 1$ kinetin, $\mathrm{RM} 2=$ MS basal media. $+\mathrm{Kn} .0 .5 \mathrm{mg} / 1+0.5 \mathrm{mg} / \mathrm{l}$ NAA, RM3 $=$ MS basal media $+480 \mathrm{mg} / \mathrm{l}$ casein hydrolysate $+1 \mathrm{mg} / \mathrm{l} \mathrm{Kinetin}$.

When shoots attained a height of 3-4 inches, they were separated and single shoots were transferred to half strength MS media for root formation. Data was recorded on regeneration percentage. After rooting, the plants were shifted in polythene bags for hardening and later were transferred to the field. To determine the existence of sugarcane mosaic virus on plants, ELISA test was performed. At the age of three months, both parents and somaclones were mechanically inoculated with sugarcane mosaic virus.Double Antibody Sandwich ELISA was performed according to method given by Kemeny and Challacambe (1989) for the screening of Sugarcane mosaic virus disease.In artificially virus, inoculated plants 10 parent plants and 32 somaclones of HSF-242 were selected for screening of virus through Das-ELISA test. In addition, SSR marker analysis was performed for the analysis of somaclonal variation among parents and somaclones. For this purpose, somaclones of HSF-242 and parent plants were selected at random. From somaclones and parent plants, DNA was extracted by CTAB method (Doyle \& Doyle, 1990). The concentration of total genomic DNA of samples was measured on spectrophotometer. The SSR products were electrophoresed to observe amplification. The bands were counted by starting from top of the lanes to bottom. Amplification profiles of all the samples were compared with each other and parent for polymorphism.Reactions were duplicated to check the consistency of the amplified products. Only easily resolved bright DNA bands were scored as presence of band (1) and absence of bands(0). Coefficient of similarity among somaclones was calculated according to Nei and Li (1978). Similarity coefficient was utilized to generate a dendrogram by means of Unweighted Pair Group Method of Arithmetic means (UPGMA).

\section{Results and Discussions}

The present study was undertaken to check the response of three sugarcane accessions viz., HSF-242, S2003-US-623, and S2003-US-633 for callogenesis, organogenesis, and presence of sugarcane mosaic disease and the existence of somaclonal variations by SSR marker.

Significant differences $(p<0.01)$ were observed among the genotypes for callus initiation frequency (callus score) using DMR test. The genotypes showed high value of callus score ranging 2.59 to 3.25. Genotype HSF-242 was highest callus producer with an average of 3.25 callus score per test tube. Gandonou et al. (2005) determined the response of three sugarcane varieties and found that callus induction ability is genotypes dependent. Satisfactory callus formation was noticed in all levels of 2, 4-D used in the study but the differences were significantly high. Mean of the doses was analyzed using DMR test, which showed that the D3 medium having $3 \mathrm{mg} / \mathrm{l}$ of 2, 4-D with 
an average of 3.5 callus scores was the best callus producer. Both the explants tried for callus production, which had highly significant effect on callus production and were different from each other. Explants showed good response to callus production but the leaf explant performed better with average callus score of 3.44 per test tube, which is statistically different from pith explant (2.387). The interactions between genotypes $\mathrm{x}$ auxin levels and auxin levels $x$ explant source were elucidated as significant by analysis of variance table (Appendix). However, the interaction of genotypes $\mathrm{x}$ explant and interaction of all three factors i.e. genotypes $\mathrm{x}$ auxin levels $\mathrm{x}$ explant was found non-significant in this study.Similar results were also reported by Seema et al. (2011) and Razaet al. (2010).

Table 1. Mean response of genotypes for callogenesis

\begin{tabular}{cc}
\hline Genotypes & Callus Initiation Frequency \\
\hline V1 & $3.250 \mathrm{~A}$ \\
V2 & $2.590 \mathrm{C}$ \\
V3 & $2.900 \mathrm{~B}$ \\
\hline
\end{tabular}

Table 2. Mean callus scores on 2, 4-D levels

\begin{tabular}{cc}
\hline 2,4-D levels & Callus scores \\
\hline D1 & $2.333 \mathrm{C}$ \\
D2 & $3.267 \mathrm{AB}$ \\
D3 & $3.500 \mathrm{~A}$ \\
D4 & $3.083 \mathrm{~B}$ \\
D5 & $2.383 \mathrm{C}$
\end{tabular}

Values followed by different letters differ significantly at $0.05 \%$ significant level.

As for as organogenesis is concerned the analysis of variance depicted that there was significant difference in the response of genotypes to the organogenesis in sugarcane. S2003-US-633 proved to be the most responsive to organogenesis with an average percent of 43.33. The minimum regeneration response was observed in S2003-US-623 with an average percent of 38.83. Similar results were alsoreported by Raza et al. (2010) in sugarcane. Khan et al. (2009) observed non-significantdifference in shoot induction from three differentsugarcane cultivars.

The Duncan's Multiple Range test showed significant difference between three regeneration media and the RM2 showed better regeneration response with average percent of 50.75 as compared to RM1 and RM3 with average percent of 39.33 and 33.67 respectively. Niaz and Quraishi (2002b) also reported that media containing Kinetin and NAA significantly increased the number of shoot production. Eldessoky et al. (2011) used sugarcane GT54-9(C9) cultivar and observed vigorous shoot regeneration when NAA was used with BAP. Similarly Khan et al. (2009) studiedthree sugarcane clonal lines andobserved best results on medium containing $1.5 \mathrm{mg} / \mathrm{K} \mathrm{Kin}+1$ $\mathrm{mg} / \mathrm{l} \mathrm{NAA}$. The leaf proved to be the best explant for regeneration of plantlets from callus with an average percent of 45.556 than pith with an average percent of 36.944. These results were consistent with the findings of Rahman et al. (2002) and Shahid et al. (2011). All the interactions like genotype x regeneration media (G x RM), genotype $\mathrm{x}$ explant sources ( $\mathrm{x}$ Exp), regeneration media $\mathrm{x}$ explant sources (RM x Exp) and genotype $\mathrm{x}$ regeneration media $\mathrm{x}$ explant sources ( $\mathrm{x}$ RM $\mathrm{x}$ Exp) were found significant in this study.

Table 3. Response of genotypes for regeneration percentage

\begin{tabular}{cc}
\hline Genotypes & Regeneration percentage \\
\hline V1 & $41.58 \mathrm{~A}$ \\
V2 & $38.83 \mathrm{~B}$ \\
V3 & $43.33 \mathrm{~A}$ \\
\hline
\end{tabular}


Table 4. The effect of regeneration media on organogenesis

\begin{tabular}{cc}
\hline Regeneration media & Regeneration percentage \\
\hline RM1 & $39.33 \mathrm{~B}$ \\
RM2 & $50.75 \mathrm{~A}$ \\
RM3 & $33.67 \mathrm{C}$ \\
\hline
\end{tabular}

Values followed by different letters differ significantly at $0.05 \%$ significant level.

When shoots attained a height of 3-4 inches, they were separated and single shoots were transferred to half strength M. S. media for root formation. After rooting, the plants were shifted in polythene bags for hardening and later were transferred to the field. To determine the existence of sugarcane mosaic virus on plants, ELISA test was performed. At the age of three months, both parents and somaclones were mechanically inoculated with sugarcane mosaic virus.

\subsection{Elisa for Sugarcane Mosaic Virus}

Significant differences were found between parent plants and somaclones for ELISA test. In artificially virus, Inoculated plants 10 parent plants and 32 somaclones of HSF-242 were selected for screening of virus through Das- ELISA test. The experiment was conducted only in half ELISA plate for the ease of handling the experiment. In the plate, a row of six wells was donated to the control treatments, two of them for positive control, two for negative control of the sugarcane mosaic virus and remaining two for the extraction buffer. Positive control always showed positive reaction; negative control showed negative reaction and same did by the buffer proving that the experiment was $100 \%$ successful.

Three parent plants out of 10 showed negative reactions to the virus while remaining seven parent plants showed positive reaction to the disease, so $70 \%$ of parent plants were found disease infected plants. Four somaclones showed positive reaction to the disease and were declared as susceptible. Two plants of somaclones showed mild reaction to virus showing them tolerant. Twenty-six somaclonal plants showed negative reaction declaring them resistant against virus. In other words $81.25 \%$ of somaclonal plants showed resistance against SCMV. The results are in confirmation of Carnot et al. (2009) who reported the production of virus free clones of sugarcane through callus culture.

Table 5. ELISA tables for SCMV

\begin{tabular}{lcccccc}
\hline \multicolumn{7}{l}{ Table I: Layout for samples loaded in ELISA plate for ELISA test } \\
\hline A & 1 & 2 & 3 & 4 & 5 & 6 \\
B & PC & PC & SC1 & SC9 & SC17 & SC25 \\
C & NC & NC & SC2 & SC10 & SC18 & SC26 \\
D & BLK & BLK & SC3 & SC11 & SC19 & SC27 \\
E & P1 & P6 & SC4 & SC12 & SC20 & SC28 \\
F & P2 & P7 & SC5 & SC13 & SC21 & SC29 \\
G & P3 & P8 & SC6 & SC14 & SC22 & SC30 \\
H & P4 & P9 & SC7 & SC15 & SC23 & SC31 \\
\hline & P5 & P10 & SC8 & SC16 & SC24 & SC32 \\
\hline A & \multicolumn{7}{r}{ Table II: Scores taken through ELISA reader for ELISA test } & & \\
B & 0.341 & 2 & 3 & 4 & 5 & 6 \\
C & 0.16 & 0.396 & 0.14 & 0.136 & 0.184 & 0.316 \\
D & 0.16 & 0.135 & 0.17 & 0.133 & 0.145 & 0.136 \\
E & 0.33 & 0.305 & 0.133 & 0.222 & 0.166 & 0.132 \\
F & 0.165 & 0.306 & 0.148 & 0.32 & 0.167 & 0.154 \\
G & 0.321 & 0.134 & 0.133 & 0.241 & 0.367 & 0.137 \\
H & 0.311 & 0.332 & 0.137 & 0.19 & 0.169 & 0.164 \\
\hline Sc & 0.142 & 0.306 & 0.131 & 0.142 & 0.344 & 0.154 \\
\hline
\end{tabular}

Key: Scoring values; value less than $0.205=$ Resistant,value between 0.25 and $0.205=$ Tolerantvalue more than $0.25=$ Susceptible. 


\subsection{Polymorphism as Revealed by SSR}

A total of 30 DNA fragments were generated by the 15 primers with an average of about 2 bands per primer. Bands that a primer yielded in the study ranged from 1 to 6 . Generally, the size and the number of bands produced were dependent upon the nucleotide sequence of the primer pair, size of the primer used and the source of the template DNA. In this study the primer used were of the size ranging from $250-1250 \mathrm{bp}$. Reactions were duplicated to check the consistency of the amplified products. Only, easily resolved bright DNA bands were scored.

Out of fifteen, eleven primers were polymorphic and four were monomorphic. They produced 30 bands, Out of which 11 bands were found to be polymorphic, showing $36.67 \%$ polymorphism. A total of 30 DNA fragments were generated by the 15 primers with an average of about 2 bands per primer. Bands that a primer yielded in the study ranged from 1 to 6 . Generally, the size and the number of bands produced were dependent upon the nucleotide sequence of the primer pair, size of the primer used and the source of the template DNA. In this study the primers used were of the size ranging from $200-750 \mathrm{bp}$. The size of the amplification products ranged from 250 to $1250 \mathrm{bp}$. The maximum number of bands (6) was produced by the primer SMs7. Shahid et al. (2011) studied the somaclonal variation in sugarcane genotype S97US297 by using 50 primers and found $67 \%$, Polymorphism using SSRs. Jannoo et al. (2001) studied diversity in 96 sugarcane genotypes with just two primer pairs and reported a high level of heterozygosity. Cordeiro et al. (2001) applied 21 primer sets to five sugarcane genotypes, and among them, 17 pairs were polymorphic, but the level of polymorphism (PIC value) in the cultivars detected by these SSRs was low (0.23). Khan et al. (2009) developed tissue culture plants using young leaf of sugarcane as explant. Genetic fidelity with 10 SSR primers was studied. A total of 37 loci were amplified, of which 30 were polymorphic, indicating $81 \%$ polymorphism. The average number of loci per locus was 3.7 , with a range of two to eight. The amplified product resulting from SSR primers ranged from 117 to $2191 \mathrm{bp}$.

Using SSR primers, the present study showed PIC values ranging from 0.00 to 0.26 . A maximum PIC value of 0.26 was obtained with SSR primers SMs48. The Parent had the greatest genetic distance 33\% with somaclone HSF-242-S-01. Among the somaclones, greatest genetic distance was found $47 \%$ between the HSF-242-S-01 and HSF-242-S-04 followed by 33\% between HSF-242-S-01 and HSF-242-S-07. Khan et al. (2009) determined a similarity coefficient matrix based on genetic distance according to Nei and Li (1979) to estimate the genetic divergence and relatedness among the somaclones developed, which ranged from 0.366 (P-100 vs P-98) to 0.951 (parent vs P-104).

A dendrogram was constructed using fifteen somaclones and a parent HSF-242, based on genetic similarity matrix generated from the fifteen polymorphic primers. The clustering pattern showed that the somaclones formed four main clusters. Cluster 1 consisted of two somaclone, HSF-242-S-12 and HSF-242-S-10. Similarly, Cluster 2 consisted of three somaclones, HSF-242-S-13, HSF-242-S-06, and HSF-242-S-04 respectively. Cluster 3 consisted of four somaclones, HSF-242-S-03, HSF-242-S-02, HSF-242-S-15, and HSF-242-S-14. Cluster 4 comprises of five somaclones HSF-242-S-08, HSF-242-S-09, HSF-242-S-07, HSF-242-S-05, and HSF-242 (Parent). Clustering and subclustering as depicted in the dendrogram certified the presence of variability at the DNA level.

Results of SSR analysis confirmed the generation of genetic variability through somaclonal variation in sugarcane genotype HSF-242. The data obtained in this study also confirmed the ability to use SSR markers for the determination and estimation of genetic similarity and dissimilarity among different sugarcane somaclones developed from the same parent. The information about genetic similarity will be helpful to create a population of genetically uniform somaclones or to select a variable somaclone with improved traits and increased productivity with respect to the parent. SSR analysis may also be very useful in breeding for early identification of the most diverse clones in a large population. This study identified the usefulness of somaclonal variation in generating variability in sugarcane genotype HSF-242 also ability SSR markers to determine the diversity among somaclones along with the parent. Very limited reports on the use of DNA markers for the estimation of somaclonal variation are available, and hence, this study should provide a benchmark for further studies.

\section{Conclusion}

From the present study, it has been concluded that SSR molecular markers can be used to check the genetic consistencies in the micro propagated plants. The observation of polymorphism between developed somaclones of sugarcane supports the conclusion that these plantlets regenerated by the method used in this study are not likely to be genetically true to their parents. Direct regeneration cannot be used for commercial propagation in sugarcane because of the genetic heterogeneity presents within the cells naturally. In genetically stable crops, direct regeneration can be used for large-scale plant production. It would suggest that, the induction of direct regeneration using immature leaf segments as described in the present study could be useful in exploring genetic 
variability or it may allow improving the existing cultivar by altering one or few traits keeping the whole genome intact.

Table 6. Polymorphism table showing information about primers

\begin{tabular}{|c|c|c|c|c|c|c|c|}
\hline $\begin{array}{l}\text { Sr. } \\
\text { No. }\end{array}$ & $\begin{array}{l}\text { Primer } \\
\text { No. }\end{array}$ & $\begin{array}{l}\text { Annealing } \\
\text { Temp. }\left({ }^{\circ} \mathrm{C}\right)\end{array}$ & $\begin{array}{r}\text { Total } \\
\text { Bands }\end{array}$ & $\begin{array}{l}\text { Polymorphic } \\
\text { Bands }\end{array}$ & $\begin{array}{c}\% \\
\text { Polymorphic }\end{array}$ & $\begin{array}{c}\text { Primer sequence } \\
\text { (Forward) } \\
\text { (Reverse) }\end{array}$ & Pic value \\
\hline 1 & SMs03 & 59 & 2 & 1 & 50 & $\begin{array}{l}\text { CATCTGCTCССТCTTCCT } \\
\text { CTCTGGCGGCTTGGTCCTG }\end{array}$ & 0.1103 \\
\hline 2 & SMs06 & 55 & 5 & 1 & 20 & $\begin{array}{l}\text { GACTCCTGTCACCGTCTTC } \\
\text { ATACTTCAACCGTCTCCTCC }\end{array}$ & 0.1103 \\
\hline 3 & SMs07 & 54.5 & 6 & 0 & 0 & $\begin{array}{l}\text { CTAAGCAAGAACACAGGAAAG } \\
\text { AGCAACAGCAGAGAGCAG }\end{array}$ & 0.0000 \\
\hline 4 & SMs08 & 53 & 2 & 1 & 50 & $\begin{array}{l}\text { CTGACTAAGGAGGAAGTGGAG } \\
\text { GACGACGATAGATGAAACA }\end{array}$ & 0.1948 \\
\hline 5 & SMs09 & 59.5 & 1 & 0 & 0 & $\begin{array}{c}\text { GAGCCGCAAGGAAGCGAC } \\
\text { CATACAAGCAGCAAGGATAG }\end{array}$ & 0.0000 \\
\hline 6 & SMs10 & 55 & 1 & 1 & 100 & $\begin{array}{l}\text { CTCTCTTCTCGTCTCCTCATT } \\
\text { GTCCTTCTTCTTCTCGTGGT }\end{array}$ & 0.1103 \\
\hline 7 & SMs11 & 57 & 1 & 0 & 0 & $\begin{array}{c}\text { ACACGCATCGCAAGAAGG } \\
\text { AAGAACACTCAACAGAAGCAC }\end{array}$ & 0.0000 \\
\hline 8 & SMs12 & 53.5 & 2 & 1 & 50 & $\begin{array}{l}\text { AAATGTCTTCGCACTAACC } \\
\text { AAGGAGATGCTGATGGAGA }\end{array}$ & 0.1103 \\
\hline 9 & SMs 16 & 55 & 2 & 1 & 50 & $\begin{array}{c}\text { CCCAGAGGACAAGGAACT } \\
\text { GTAATGGAAGGAAGCAACTGA }\end{array}$ & 0.1103 \\
\hline 10 & SMs45 & 54 & 1 & 1 & 100 & $\begin{array}{c}\text { СТTСССТСССТСТССТСТ } \\
\text { AGCCTTCTACTAAACTATCTGCT }\end{array}$ & 0.1948 \\
\hline 11 & SMs46 & 53.5 & 1 & 1 & 100 & $\begin{array}{l}\text { GTGAGTGAGACCAGACCAG } \\
\text { CCGTGCTGTAGTTGTTGTAG }\end{array}$ & 0.1948 \\
\hline 12 & SMs47 & 54 & 1 & 1 & 100 & $\begin{array}{l}\text { ATACGCTACTCTGAATCCCAC } \\
\text { CAATCACTATGTAAGGCAACA }\end{array}$ & 0.1103 \\
\hline 13 & SMs48 & 55 & 1 & 1 & 100 & $\begin{array}{c}\text { АCTCCTCTTCСтCTTCCTCTT } \\
\text { GTTGTTCCCGTTCCCGCC }\end{array}$ & 0.2583 \\
\hline 14 & SMs49 & 60 & 2 & 1 & 50 & $\begin{array}{c}\text { ACTCGGTCATCTCATCACTC } \\
\text { GTTCTTCGGGTCATCTGG }\end{array}$ & 0.1948 \\
\hline 15 & SMs50 & 55 & 2 & 0 & 0 & $\begin{array}{l}\text { ACGGTGAGCGAGGACTAC } \\
\text { CTTGGGTGGCATCAGGAA }\end{array}$ & 0.0000 \\
\hline Total & & & 30 & 11 & & & \\
\hline
\end{tabular}




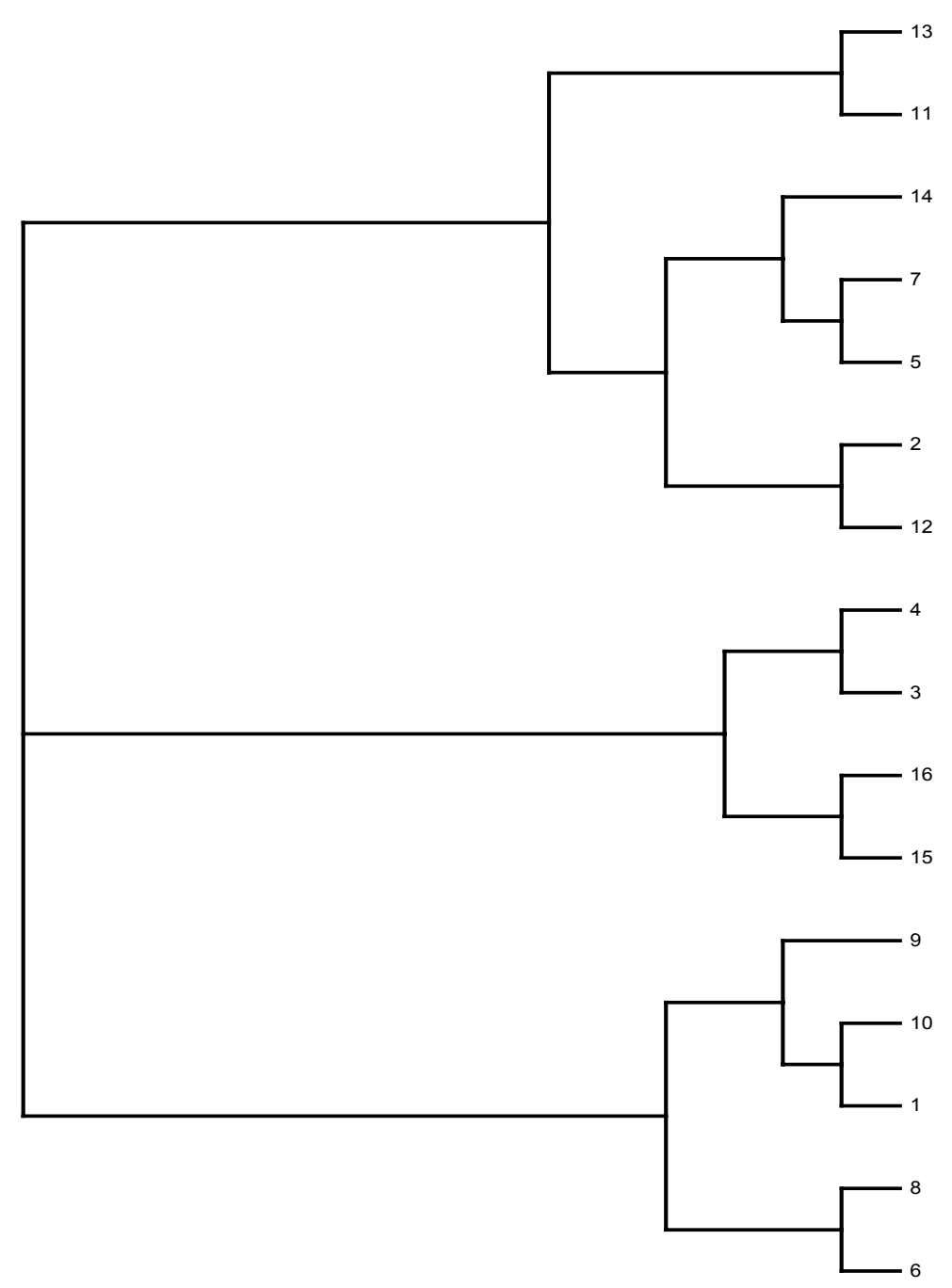

Figure 1. Dendrogram

Dendrogram of somaclones and their parent HSF-242 as revealed by SSR markers. S-01 = HSF-242 (Parent); S-02 $=$ HSF-242-S-01; S-03 = HSF-242-S-02; S-04 = HSF-242-S-03; S-05 = HSF-242-S-04; S-06 = HSF-242-S-05; S-07; HSF-242-S-06; S-08 = HSF-242-S-07; S-09 = S97US297-S-08; S-10 = HSF-242-S-09; S-11 = HSF-242-S-10; S-12 = HSF-242-S-11; S-13 = HSF-242-S-12; S-14=HSF-242-S-13; S-15 = HSF-242-S-14; S-16 $=$ HSF-242-S- 15 .

\section{References}

Anonymous. (2011). Economic Survey of Pakistan, Govt. of Pakistan Finance and Economic Affairs Division. Islamabad Pakistan.

Carnot, A. C., Zachée, A., Ivanovich, P. Y., \& Alexandrovna, K. M. (2009). In vitro cleaning of sugarcane (Saccharum officinarum) explants against the viral infections by application of the viral inhibitors (DHHT and virazol): a preliminary study. Afr. J. Micro. Res., 3(6), 339-343.

Doyle, J. J., \& Doyle, J. L. (1990). Isolation of plant DNA from fresh tissue. Focus., 12, 13-15.

Eldessoky, D. S., Ismail, R. M., Hadi, A., Hadi, A., Abdallah, N. (2011). Establishment of regeneration and transformation system of sugarcane cultivar GT54-9 (C9). GM Crops, 2(2), 126-134. http://dx.doi.org/10.4161/gmer.2.2.17288

Gandonou, C., Abrini, J., Idaomar, M., \& Senhaji, N. S. (2005). Response of sugarcane (Saccharum sp.) varieties to embryogenic callus induction and invitro salt stress. J. Biotech., 4(4), 350-354. 
Jannoo, N., Forget, L., \& Dookun, A. (2001). Contribution of Microsatellites to Sugarcane Breeding Program in Mauritius. International Society of Sugar Cane Technologists, Proceedings of the XXIV Congress (pp. 637-639), Brisbane.

Kemeny, D. M., \& Challacombe, S. J. (1989). ELISA and Other Solid Phase Immunoas-Says (pp. 1-16). USA: John Wiley and Sons.

Khan, I. A., Dahot, M. U., Seema, N., Yasmine, S., Bibi, S., Raza, G., Khatri, A., \& Naqvi, M. H. (2009). Direct regeneration of sugarcane plantlets: a tool to unravel genetic heterogeneity. Pak. J. Bot., 41(2), 797-814.

Khaliq, A., Ashfaq, M., Akram, W., Choi, J. K., \& Lee, J. (2005). Effect of plantfactors, sugar contents, and control methods on the Top Borer (Scirpophaganivella F.) Infestation in selected varieties of sugarcane. Entomological Res., 35, 153-160. http://dx.doi.org/10.1111/j.1748-5967.2005.tb00152.x

Murashige, T., \& Skoog, F. (1962). A revised medium for rapid growth and bioassays with tobacco tissue cultures. Physiol. Plant., 15, 473-497. http://dx.doi.org/10.1111/j.1399-3054.1962.tb08052.x

Nasir, N. M., Qureshi, R. H., \& Aslam, M. (2000). Effect of salinity on emergence of sugarcane lines. Pak. Sugar $J ., 15,12-14$.

Nei \& Li. (1978). Estimation of average heterozygosity and genetic distance from a small number of individual. Genet., 89, 583-590.

Niaz, F., \& Quraishi, A. (2002a). Studies on Somatic Embryogenesis in Sugarcane. J. Biol. Sci., 2(2), 67-69. http://dx.doi.org/10.3923/jbs.2002.67.69

Niaz, F., Quraishi, A. (2002b). Effect of growth regulators on regeneration potential of two Sugarcane cultivars. Pak. J. Biol. Sci., 2(2), 67-69.

Rahman, S. U., Shahid, M. T. H., Hussain, M., Tanvir, M. K., \& Javed, M. A. (2002). Genotypic effect on callogenesis and organogenesis in sugarcane. Pak. Sugar J., 17(6), 13-20.

Raza, G., Ali, K., Mukhtar, Z., Mansoor, S., Arshad, M., \& Asad, S. (2010). The response of sugarcane (Saccharumofficinarum L) genotypes to callus induction, regeneration and different concentrations of the selective agent (geneticin -418). Afr. J. Biotech., 9(51), 8739-8747.

Seema, N., Oad, F. C., Khan, I. A., Tunio, S., Siddiqui, M. A., Yasmin, S., ... Bibi, S. (2011). Influence of phytohormone on the organogenesis of sugarcane. Pak. J. Bot., 43(3), 1531-1534.

Shahid, M. T. H., Khan, F. A., Saeed, A., \& Fareed, I. (2011). Variability of red rot-resistant somaclones of sugarcane genotype S97US297 assessed by RAPD and SSR. Genet. Mol. Res., 10(3), 1831-1849. http://dx.doi.org/10.4238/vol10-3gmr1122

\section{Appendices}

Table 1. Analysis of variance table for callus initiation frequency (CIF)

\begin{tabular}{ccccc}
\hline Source & D.F & S.S & M.S & F-VALUE \\
\hline Genotypes (G) & 2 & 21.807 & 10.903 & $24.6145^{* *}$ \\
2,4-D levels (D) & 4 & 66.913 & 16.728 & $37.7646^{* *}$ \\
G x D & 8 & 7.627 & 0.953 & $2.1522^{*}$ \\
Explant (Exp.) & 1 & 83.213 & 83.213 & $187.8562^{* *}$ \\
G x Exp. & 2 & 0.647 & 0.323 & $0.7299^{\mathrm{ns}}$ \\
D x Exp. & 4 & 5.220 & 1.305 & $2.9461^{*}$ \\
G x D x Exp. & 8 & 2.720 & 0.340 & $0.7676^{\mathrm{ns}}$ \\
Error & 270 & 119.600 & 0.443 & \\
Total & 299 & 307.747 & & \\
\hline
\end{tabular}

Coefficient of Variation: $22.85 \%$.

$* *=$ Highly significant at $\mathrm{p}<0.01 ; *=$ Significant at $\mathrm{p}<0.05 ; \mathrm{ns}=$ Non significant. 
Table 2. Mean of callus scores for genotype x 2,4-D interaction

\begin{tabular}{cccc}
\hline & $\mathrm{V} 1$ & $\mathrm{~V} 2$ & $\mathrm{~V} 3$ \\
\hline $\mathrm{D} 1$ & $2.75 \mathrm{EF}$ & $2.05 \mathrm{HI}$ & $2.20 \mathrm{GH}$ \\
$\mathrm{D} 2$ & $3.45 \mathrm{ABC}$ & $3.10 \mathrm{BCDE}$ & $3.25 \mathrm{BCD}$ \\
D3 & $3.75 \mathrm{~A}$ & $3.25 \mathrm{BCD}$ & $3.50 \mathrm{AB}$ \\
D4 & $3.30 \mathrm{ABCD}$ & $2.90 \mathrm{DEF}$ & $3.05 \mathrm{BCDE}$ \\
D5 & $3.00 \mathrm{CDE}$ & $1.65 \mathrm{I}$ & $2.50 \mathrm{FG}$ \\
\hline
\end{tabular}

Table 3. Mean of callus scores for 2,4-D x explant source interaction

\begin{tabular}{ccc}
\hline & Ex1 & Ex2 \\
\hline D1 & $3.067 \mathrm{~B}$ & $1.600 \mathrm{D}$ \\
D2 & $3.733 \mathrm{~A}$ & $2.800 \mathrm{BC}$ \\
D3 & $3.833 \mathrm{~A}$ & $3.167 \mathrm{~B}$ \\
D4 & $3.600 \mathrm{~A}$ & $2.567 \mathrm{C}$ \\
D5 & $2.967 \mathrm{~B}$ & $1.800 \mathrm{D}$ \\
\hline
\end{tabular}

Table 4. Analysis of variance table for regeneration percentage (\%)

\begin{tabular}{ccccc}
\hline SOURCE & DF & SS & MS & F-VALUE \\
\hline Genotype (G) & 2 & 617.500 & 308.750 & $5.4560^{* *}$ \\
RM level (RM) & 2 & 9085.833 & 4542.917 & $80.2784^{* *}$ \\
G x RM & 4 & 614.167 & 153.542 & $2.7133^{*}$ \\
Explant (Exp.) & 1 & 3336.806 & 3336.806 & $58.9651^{* *}$ \\
G x Exp. & 2 & 370.278 & 185.139 & $3.2716^{*}$ \\
RM x Exp. & 2 & 1183.611 & 591.806 & $10.4579^{* *}$ \\
G x RM x Exp. & 4 & 568.056 & 142.014 & $2.5095^{*}$ \\
Error & 162 & 9167.500 & 56.590 & \\
Total & 179 & 24943.750 & & \\
\hline
\end{tabular}

Coefficient of Variation: $18.24 \%$.

$* *=$ Highly significant at $\mathrm{p}<0.01 ; *=$ Significant at $\mathrm{p}<0.05$; ns $=$ Non significant.

Table 5. Response of genotype $\mathrm{x}$ regeneration media for organogenesis

\begin{tabular}{cccc}
\hline & RM1 & RM2 & RM3 \\
\hline V1 & $41.25 \mathrm{C}$ & $53.00 \mathrm{~A}$ & $30.50 \mathrm{D}$ \\
V2 & $36.75 \mathrm{C}$ & $47.75 \mathrm{~B}$ & $32.00 \mathrm{D}$ \\
V3 & $40.00 \mathrm{C}$ & $51.50 \mathrm{AB}$ & $38.50 \mathrm{C}$ \\
\hline
\end{tabular}

Table 6. Response of genotype $\mathrm{x}$ explants interaction for regeneration

\begin{tabular}{ccc}
\hline & Exp1 & Exp2 \\
\hline V1 & $44.83 \mathrm{~B}$ & $38.33 \mathrm{CD}$ \\
V2 & $42.17 \mathrm{BC}$ & $35.50 \mathrm{D}$ \\
V3 & $49.67 \mathrm{~A}$ & $37.00 \mathrm{D}$ \\
\hline
\end{tabular}


Table 7. Response of Regeneration media x Explant source for regeneration \%

\begin{tabular}{lcc}
\hline & Exp1 & Exp2 \\
\hline RM1 & $44.00 \mathrm{~B}$ & $34.67 \mathrm{C}$ \\
RM2 & $58.00 \mathrm{~A}$ & $43.50 \mathrm{~B}$ \\
RM3 & $34.67 \mathrm{C}$ & $32.67 \mathrm{C}$ \\
\hline
\end{tabular}

Table 8. Response of Genotypes x Regeneration media x Explant source for regeneration \%

\begin{tabular}{|c|c|c|c|c|c|c|}
\hline & \multicolumn{2}{|c|}{ V1 } & \multicolumn{2}{|c|}{ V2 } & \multicolumn{2}{|c|}{ V3 } \\
\hline & Ex1 & Ex2 & Ex1 & Ex2 & Ex1 & Ex2 \\
\hline RM1 & $45.50 \mathrm{BC}$ & $37.00 \mathrm{DEF}$ & $41.50 \mathrm{CDE}$ & $32.00 \mathrm{FG}$ & $45.00 \mathrm{BC}$ & 35.00 DEFG \\
\hline RM2 & $61.00 \mathrm{~A}$ & $45.000 \mathrm{BC}$ & $51.00 \mathrm{~B}$ & $44.50 \mathrm{BC}$ & $62.00 \mathrm{~A}$ & $41.00 \mathrm{CDE}$ \\
\hline RM3 & $28.00 \mathrm{G}$ & $33.00 \mathrm{FG}$ & $34.00 \mathrm{EFG}$ & $30.00 \mathrm{FG}$ & $42.00 \mathrm{CD}$ & 35.00 DEFG \\
\hline
\end{tabular}

